\title{
Influence of conservation tillage on Greenhouse gas fluxes and crop productivity in spring-wheat agroecosystems on the Loess Plateau of China
}

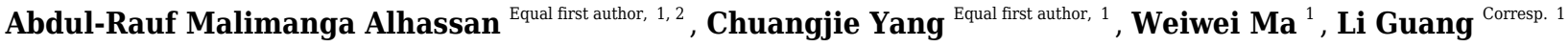 \\ ${ }^{1}$ College of Forestry, Gansu Agricultural University, Lanzhou, Gansu, China \\ 2 Department of Water Resources Development, University of Environment and Sustainable Development, Somanya, Eastern Region, Ghana \\ Corresponding Author: Li Guang \\ Email address: liguang468@yahoo.com
}

The effects of climate change such as dry spells, floods and erosion heavily impact agriculture especially smallholder systems on the Northwestern Loess Plateau of China. Nonetheless agriculture also contributes to global warming through the emission of greenhouse gases such as $\mathrm{CO}_{2}, \mathrm{CH}_{4}$ and $\mathrm{N}_{2} \mathrm{O}$. Yet this complex conundrum can be alleviated and mitigated through sound soil and water management practices. Despite considerable literature on Conservation Agriculture (CA) as a strategy to improve the resilience and mitigation capacity of agroecosystems, there is still paucity of information on the impacts of CA on crop production and environmental quality on the Plateau. In order to fill this gap this study examined the effects of no-till and straw mulch on crop productivity and greenhouse gas fluxes in agroecosystems on the Plateau where farmers' common practice of conventional tillage (CT) was tested against 3 CA practices:

conventional tillage with straw mulch (CTS), no-till (NT) and no-till with straw mulch (NTS). The results indicated that all 3 CA practices (CTS, NT and NTS) markedly increased soil water content (SWC), soil organic carbon (SOC) and soil total nitrogen (STN) but reduced soil temperature (ST). Average grain yields were $854.46 \pm 76.51,699.30 \pm 133.52$ and $908.18 \pm 38.64 \mathrm{~kg} \mathrm{ha}^{-1}$ respectively under CTS, NT and NTS indicating an increase by approximately $33 \%, 9 \%$ and $41 \%$ respectively compared with CT $\left(644.61 \pm 76.98 \mathrm{~kg} \mathrm{ha}^{-1}\right)$. There were significant $(p<0.05)$ reductions of $\mathrm{Net}^{\mathrm{CO}_{2}}$ emissions under NT $(7.37 \pm 0.89$ tCO2e ha-1 $\left.\mathrm{y}^{-1}\right)$ and NTS $\left(6.65 \pm 0.73\right.$ tCO2e ha $\left.{ }^{-1} \mathrm{y}^{-1}\right)$ compared with CTS $(10.65 \pm 0.18$ tCO2e ha $\left.{ }^{-1} \mathrm{y}^{-1}\right)$ and CT $\left(11.14 \pm 0.58\right.$ tCO2e ha- $\left.{ }^{-1} \mathrm{y}^{-1}\right)$. All the treatments served as sinks of $\mathrm{CH}_{4}$ but NTS had the highest absorption capacity $\left(-0.27 \pm 0.024\right.$ tCO2e ha $\left.{ }^{-1} y^{-1}\right)$ and increased absorption significantly $(p<0.05)$ compared with CT $\left(-0.21 \pm 0.017\right.$ tCO2e ha $\left.{ }^{-1} y^{-1}\right)$ however 
CA did not reduce emissions of $\mathrm{N}_{2} \mathrm{O}$. These had an influence on Global warming potential (GWP) as NT and NTS resulted in significant reduction in net GWP. Grain yield was significantly correlated positively with SOC and STN $(p<0.05)$; ecosystem respiration was also significantly correlated with SWC and ST while $\mathrm{CH}_{4}$ flux was highly correlated with ST $(p<0.001)$. Crop yield and GHG responses to CA were controlled by soil hydrothermal and nutrient changes, thus improving these conditions through adoption of sustainable soil moisture improvement practices such as no-till, straw mulch, green manuring, contour ploughing and terracing can improve crop resilience to climate change and reduce GHG emissions in arid and semi-arid regions. 


\section{Influence of conservation tillage on Greenhouse gas}

2 fluxes and crop productivity in spring-wheat

3 agroecosystems on the Loess Plateau of China

4

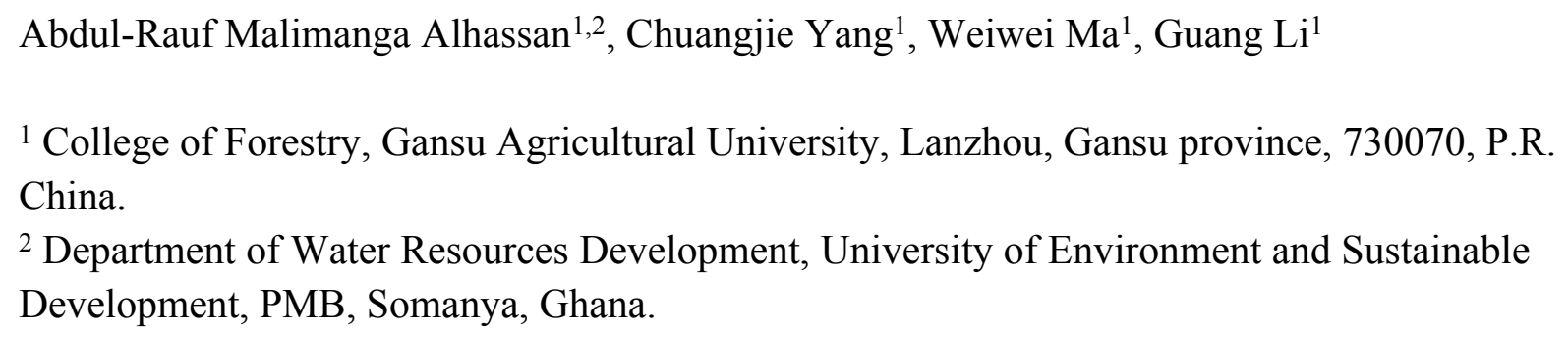

\section{Abstract}

The effects of climate change such as dry spells, floods and erosion heavily impact agriculture especially smallholder systems on the Northwestern Loess Plateau of China. Nonetheless agriculture also contributes to global warming through the emission of greenhouse gases such as $\mathrm{CO}_{2}, \mathrm{CH}_{4}$ and $\mathrm{N}_{2} \mathrm{O}$. Yet this complex conundrum can be alleviated and mitigated through sound soil and water management practices. Despite considerable literature on Conservation Agriculture (CA) as a strategy to improve the resilience and mitigation capacity of agroecosystems, there is still paucity of information on the impacts of CA on crop production and environmental quality on the Plateau. In order to fill this gap this study examined the effects of no-till and straw mulch on crop productivity and greenhouse gas fluxes in agroecosystems on the Plateau where farmers' common practice of conventional tillage (CT) was tested against 3 CA practices: conventional tillage with straw mulch (CTS), no-till (NT) and no-till with straw mulch (NTS). The results indicated that all 3 CA practices (CTS, NT and NTS) markedly increased soil water content (SWC), soil organic carbon (SOC) and soil total nitrogen (STN) but reduced soil temperature (ST). Average grain yields were $854.46 \pm 76.51,699.30 \pm 133.52$ and $908.18 \pm 38.64 \mathrm{~kg} \mathrm{ha}^{-1}$ respectively under CTS, NT and NTS indicating an increase by approximately $33 \%, 9 \%$ and $41 \%$ respectively compared with CT $\left(644.61 \pm 76.98 \mathrm{~kg} \mathrm{ha}^{-1}\right)$. There were significant $(p<0.05)$ reductions of Net $\mathrm{CO}_{2}$ emissions under NT $\left(7.37 \pm 0.89 \mathrm{tCO}^{\mathrm{e}} \mathrm{ha}^{-1} \mathrm{y}^{-1}\right)$ and NTS $\left(6.65 \pm 0.73\right.$ tCO2e ha $\left.{ }^{-1} \mathrm{y}^{-1}\right)$ compared with CTS $\left(10.65 \pm 0.18\right.$ tCO2e ha $\left.^{-1} \mathrm{y}^{-1}\right)$ and CT (11.14 $\left.\pm 0.58 \mathrm{tCO} 2 \mathrm{e} \mathrm{ha}^{-1} \mathrm{y}^{-1}\right)$. All the treatments served as sinks of $\mathrm{CH}_{4}$ but NTS had the highest absorption capacity $\left(-0.27 \pm 0.024 \mathrm{tCO}^{\mathrm{e}} \mathrm{ha}^{-1} \mathrm{y}^{-1}\right)$ and increased absorption significantly $(\mathrm{p}<0.05)$ compared with CT $\left(-0.21 \pm 0.017\right.$ tCO2e $\left.\mathrm{ha}^{-1} \mathrm{y}^{-1}\right)$ however CA did not reduce emissions of $\mathrm{N}_{2} \mathrm{O}$. 
40 These had an influence on Global warming potential (GWP) as NT and NTS resulted in 41 significant reduction in net GWP. Grain yield was significantly correlated positively with SOC 42 and STN $(p<0.05)$; ecosystem respiration was also significantly correlated with SWC and ST 43 while $\mathrm{CH}_{4}$ flux was highly correlated with ST $(p<0.001)$. Crop yield and GHG responses to CA 44 were controlled by soil hydrothermal and nutrient changes, thus improving these conditions 45 through adoption of sustainable soil moisture improvement practices such as no-till, straw mulch, 46 green manuring, contour ploughing and terracing can improve crop resilience to climate change

Keywords: climate-smart agriculture; sustainability; crop productivity; global warming; carbon dioxide, methane, nitrous oxide.

51 and reduce GHG emissions in arid and semi-arid regions.

\section{Introduction}

Agricultural soils are potential sources of carbon dioxide $\left(\mathrm{CO}_{2}\right)$, nitrous oxide $\left(\mathrm{N}_{2} \mathrm{O}\right)$ and methane $\left(\mathrm{CH}_{4}\right)$ (Smith et al., 2008). These gases constitute the most important greenhouse gases (GHGs) and their emissions from agriculture and land-use change account for one-third of global warming (Cole et al., 1997). Meanwhile agriculture is also one of the most affected sectors by climate change through several climate induced processes. Changes in hydrological cycle and temperature affects crop cultivation in various ways: higher temperatures may cause shortening of the crop cycle in arid and semi-arid areas, resulting in low yields (IPCC, 2007) while lower precipitation may cause moisture deficit under rainfed cultivation, which could also result in significant yield decline (Calzadilla et al., 2013). In all these complexities, agriculture still holds a potential to adapt to climate change through sound management practices and as well reduce its contribution to global warming through carbon sequestration and less GHG emissions.

Wheat is a crop with global importance (Huang et al., 2003) and is central to global food security. Its cultivation in China occupied approximately 24 million hectares (Li et al., 2019). On the Loess Plateau region of Western China wheat accounts for 35\% of the region's total production area and $40 \%$ of total crop production volumes (An et al., 2014). The Loess Plateau however is a fragile dryland area with abundant smallholder farmers whose activities are threatened by wind and water erosion. Coupled with wide adoption of rainfed agriculture and conventional tillage (CT) practices, the resilience of production systems to climate change is threatened by the intricate interaction of environmental and anthropogenic factors, increasing the risks of farmers to food insecurity and poor livelihood. Innovative soil management practices hold huge potential in alleviating the effect of climate change on production systems and vice versa.

Tillage, though an important component of crop cultivation may affect soil carbon (C) cycle. The practice of CT where mechanical means is employed in land preparation causes rapid soil organic matter decomposition and oxidation of soil $\mathrm{C}$ to $\mathrm{CO}_{2}$ (Reicosky, 1997; Six et al., 2000). This may affect changes in soil structure which could influence soil water holding capacity, soil 
79 fertility and GHG emissions. Under conservation tillage soil disturbance is minimal which 80 maintains soil physico-chemical and biological properties, thereby improving soil water storage 81 capacity. In addition, the provision of soil cover or amendments increases soil organic matter and 82 nutrient content which may enhance crop yield. Crop yield is dependent on soil suitability and 83 limited by soil physical properties (Indoria et al., 2016), chemical properties (Wang et al., 2008) 84 and biological properties (Woźniak \& Gos, 2014). Management practices that would facilitate 85 meeting global food demand and conserving the already stressed environment (Lal, 2005) is key 86 to sustainable crop production. No-till with residue retention is a key conservation agriculture 87 (CA) practice that has been reported to improve soil condition (Li et al., 2014), increased rainfed 88 crop yield (Pittelkow et al. 2015) and increased soil C stocks (Paustian et al., 2006). But these 89 responses to conservation tillage is variable in literature with reports of increased yields (Fabrizzi 90 et al. 2005), reduced yields (Taa et al., 2004) and no effect (Lampurlanés et al., 2002). Different 91 responses are dependent on several factors such as environment, duration of implementation and 92 types of conservation practices adopted (Zheng et al., 2014). It is not clear how the drylands of 93 the Loess plateau will respond to conservation tillage. Furthermore, studies on GHG response to 94 conservation tillage on the Loess Plateau are scarce and much is still unknown. This research is 95 needed in order to provide tailor-made recommendations for sustainable and climate-smart crop production on the plateau.

Thus the objective of this study was (1) to examine the influence of no-till and straw mulching soil management practices on crop yield (2) to analyse the dynamics of $\mathrm{CO}_{2}, \mathrm{CH}_{4}$ and $\mathrm{N}_{2} \mathrm{O}$ fluxes as affected by conservation tillage and (3) to identify the mechanisms that control the responses of yield and greenhouse gases to tillage practices in dryland areas.

101

\section{2}

\section{Materials \& Methods}

\section{Study area}

104

105

106

107

108

109

110

111

112

113

114

115

116

117
This experiment was conducted for two years (2017-2018) in the Anjiapo catchment on the western Loess Plateau in Gansu province at the Soil and Water Conservation Research Institute in Dingxi (35 34' 53’N, 104'38'30'E; $2000 \mathrm{~m}$ above sea level). For this study we have continuous data of forty two years (precipitation-385 mm, evaporation-1531 mm, sunshine duration-2448 h, temperature- $7.1{ }^{\circ} \mathrm{C}$, and frost free period-153 days). The soil is formed from Loess with a sandy-loam texture, with average soil bulk density of $1.26 \mathrm{gcm}^{-3}$. Average soil organic carbon (SOC) was $6.21 \mathrm{gkg}^{-1}$ while total nitrogen content was $0.61 \mathrm{gkg}^{-1}$. Precipitation, maximum and minimum temperatures for the experimental period are shown in Fig. 1.

\section{Fig. 1.}

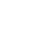


118 Experimental Design

119 Four tillage treatments were established in a randomized complete block design. The

120

121

122

123

124

125

126

127

128

129

130

131

132

133

134

135

136

137

138

139

140

141

142

143

144

145

146

147

148

149

150

151

152 treatments included conventional tillage (CT), conventional tillage with straw mulch (CTS), notill (NT) and no-till with straw mulch (NTS). Sowing was conducted in spring (mid-March) in both years while crops were harvested in late July to early August. In the tilled plots, soils were tilled at two different times by manual inversion with shovels to a depth of $20 \mathrm{~cm}$; first in October of the previous year and again in March just before planting. Glyphosate (30\%) herbicide was applied to control weeds in the plots. Wheat straw (dry weight of 3.75 ton/ha) was spread uniformly on all straw-treated plots immediately after planting. Chemical composition of the wheat straw is shown in Table 1. Planting was done manually by the drill method in rows with row spacing of $25 \mathrm{~cm}$ while fertilizers were applied to all the plots using Di-ammonium phosphate $\left(\mathrm{N}+\mathrm{P}_{2} \mathrm{O}_{5}\right)$ at a rate of $146 \mathrm{~kg} / \mathrm{ha}$ and urea $(46 \%)$ at a rate of $63 \mathrm{~kg} / \mathrm{ha}$. Three rows per plot were harvested for determination of aboveground and below ground plant products at physiological maturity. Aboveground biomass was determined by oven drying of plants at $80{ }^{\circ} \mathrm{C}$ to constant weight (Alhassan et al. 2018), while grain yields were determined by oven-drying at $105^{\circ} \mathrm{C}$ for 45 minutes (Yeboah et al. 2016a).

\section{Table 1}

\section{Sampling and Measurements}

\section{Soil Properties}

Soil water content and soil temperature at 0-10 $\mathrm{cm}$ depth were measured using EM50 data logger and GS3 soil moisture, temperature and EC sensor (Decagon Devices, Inc., Pullman, Washington). The data was sampled every 2 minutes and subsequently downloaded onto the computer using the $\mathrm{ECH}_{2} \mathrm{O}$ software. Chamber temperature was recorded using a handheld digital thermometer (JM624, Jinming Instrument Co., Tianjing, China). Soil moisture and soil temperature data were taken concurrently with gas sampling.

Soils were sampled at 0-10, 10-20 and 20-40 cm with a soil auger (4 cm diameter) for determination of soil organic carbon (SOC) and soil total nitrogen (STN). SOC was determined by the Walkley-Black dichromate oxidation method (Nelson \& Sommers, 1982) while STN was determined by the Kjeldahl digestion and distillation procedure as described by Bremner \& Mulvaney (1982). 


\section{Gas sampling and Flux measurements}

154

155

156

157

158

159

160

161

162

163

164

165

166

167

168

169

170

171

172

173

174

175

176

177

178

179

180

181

182

183

184

185

186

187

188

189

190

The gas sampling procedure was conducted between September, 2017 and January, 2019. The static dark chamber and Gas chromatography (GC) method as described by Wang and Wang (2003) were used for gas sampling and flux measurements. In each plot (a total of 12 plots), a stainless steel base with a collar $(50 \times 50 \times 10 \mathrm{~cm})$ was installed to support placement of the sampling chamber $(50 \times 50 \times 50 \mathrm{~cm})$ for gas sampling. Air samples were drawn from the chambers concurrently for the 3 replicates of each treatment. Samples were drawn at 5 different times at $0,9,18,27$, and 36 minutes respectively using $150 \mathrm{ml}$ gas-tight polypropylene syringes and released into $100 \mathrm{ml}$ aluminum foil sampling bags (Shanghai Sunrise Instrument Co. Ltd, Shanghai). Gas samples were then analyzed in the laboratory with a GC system (Echrom GC A90, China) equipped with a flame ionization detector (FID) for $\mathrm{CH}_{4}$ and $\mathrm{CO}_{2}$ analysis and Electron capture detector (ECD) for $\mathrm{N}_{2} \mathrm{O}$ analysis. The FID operates at a temperature of $250^{\circ} \mathrm{C}$, and $\mathrm{H}_{2}$ flow rate of $35 \mathrm{~cm}^{3} \mathrm{~min}^{-1}$. Peak areas of $\mathrm{CO}_{2}, \mathrm{CH}_{4}$ and $\mathrm{N}_{2} \mathrm{O}$ were analyzed in EchromChemLab software. Before the analyses of sample gases, calibrations were done with standard gas obtained from Shanghai Jiliang Standard Reference Gases Co., Ltd, China. Concentrations of the standard gases were 456.00 ppmv for $\mathrm{CO}_{2}, 2.00$ ppmv for $\mathrm{CH}_{4}$ and 0.355 ppmv for $\mathrm{N}_{2} \mathrm{O}$. The sample gas concentrations obtained for the five sampling times were plotted against time in order to obtain the change in concentration over the sampling time. $\mathrm{CO}_{2}$ emissions in terms of ecosystem respiration $\left(\mathrm{R}_{\text {eco }}\right), \mathrm{CH}_{4}$ and $\mathrm{N}_{2} \mathrm{O}$ fluxes were calculated as shown in the supplemental file 1 following equation 1(Wei et al. 2014). Further flux analysis, soil carbon input components, and global warming potential were calculated from equations 2-10 as shown in supplemental file 1 (Bolinder et al., 2007; Zhang et al., 2009; Huang et al., 2007; IPCC, 2013).

\section{Statistical Analysis}

The data was analyzed in SPSS, version 22 (IBM Corporation, Chicago, USA). One-way Anova was conducted and treatment means were separated using the Duncan's multiple range tests (DMRT) at $p<0.05$. Linear and non-linear regressions were used to examine the relationships between parameters crop yields, soil properties and greenhouse gas fluxes. The exponential and power equations were used to describe the relationship between ecosystem respiration, soil temperature and soil water content as shown in equations 11 and 12 respectively (supplemental file 1). 
191 Results

192 Soil water content and Soil temperature

193 Soil water content (SWC) was higher in NTS than all other treatments while CT had the 194 lowest SWC at almost all sampling times (Fig. 2a). Conventional tillage with straw mulch (CTS) 195 however stored more moisture than NT and CT at most sampling times. The highest SWC values 196 were recorded in the growing season between July and September.

197 Soil temperature, as shown in Fig. $2 \mathrm{~b}$ showed peak temperatures occurring in June-August. The 198 highest temperatures were recorded in CT in most times while NTS and NT had the least 199 temperatures in most instances.

200 Fig 2.

201

202

203

\section{Soil organic carbon (SOC) and Soil Total Nitrogen (STN)}

205

206

207

208

209

210

211

212

213

214

215

216

217

218

219

220

221

222

223

224

225

226

227

228

Conservation Agricultural practices increased SOC at all depths (Fig. 3 a, b, c). At the 0-10 $\mathrm{cm}$ and 10-20 cm depths, SOC was increased significantly $(\mathrm{p}<0.05)$ under CTS, NT and NTS. For the $0-10 \mathrm{~cm}$ SOC values were $9.98 \pm 0.73,11.97 \pm 0.5,11.81 \pm 0.09$ and $12.57 \pm 0.62 \mathrm{gkg}^{-1}$ respectively for CT, CTS, NT and NTS. Compared with CT, SOC was increased by $19.95 \%$, $18.38 \%$ and $26.03 \%$ respectively under CTS, NT and NTS within the $0-10 \mathrm{~cm}$ soil depth. A similar trend was observed within the $10-20 \mathrm{~cm}$ profile where SOC was also increased by $12.51 \%, 10.76 \%$ and $14.26 \%$ respectively under CTS, NT and NTS. However in the $20-40 \mathrm{~cm}$ depth there was a little deviation where SOC in NTS and CTS were significantly greater than CT but NT showed no significant difference. Meanwhile SOC decreased along soil depth irrespective of treatment.

There was also significance $(p<0.05)$ in STN variations among treatments in the $0-10 \mathrm{~cm}$ and the 10-20 cm depths (Fig $3 \mathrm{~d}$, e, f). At the 0-10 cm depth STN values were 0.29 \pm 0.04 , $0.36 \pm 0.03,0.42 \pm 0.01$ and $0.49 \pm 0.03 \mathrm{gkg}^{-1}$ in CT, CTS, NT and NTS respectively. Compared with the control (CT), STN was increased significantly $(p<0.05)$ by $21.59 \%, 43.75 \%$ and $65.91 \%$ respectively in CTS, NT and NTS. Similarly, within the 10-20 cm depth, STN was significantly $(p<0.05)$ increased under CTS $\left(0.20 \pm 0.07 \mathrm{gkg}^{-1}\right)$, NT $\left(0.24 \pm 0.10 \mathrm{gkg}^{-1}\right)$ and NTS $\left(0.31 \pm 0.01 \mathrm{gkg}^{-}\right.$ $\left.{ }^{1}\right)$ compared with CT $\left(0.17 \pm 0.01 \mathrm{gkg}^{-1}\right)$. Nonetheless there were no significant differences $(p>$ 0.05 ) in STN within the $20-40 \mathrm{~cm}$ depth. However there were observed reductions of STN along soil depth in all treatments.

\section{Fig 3.}


229

230

231

232

233

234

235

236

237

238

239

240

241

242

243

244

245

246

247

248

249

250

251

252

253

254

255

256

257

258

259

260

261

262

263

264

265

\section{Grain Yield}

Tillage and straw treatments influenced grain yield in both years (Table 2). Average grain yields (2017-2018) were 644.61 $\pm 116.40,854.46 \pm 76.51,699.30 \pm 133.52$ and $908.18 \pm 38.64 \mathrm{~kg}^{2} \mathrm{ha}^{-}$ ${ }^{1}$ respectively for CT, CTS, NT ad NTS. This means grain yield was increased by $32.55 \%, 8.48 \%$ and $40.89 \%$ respectively under CTS, NT and NTS compared with CT. CTS and NTS increased grain yield significantly $(p<0.05)$ for the period (2017-2018) but grain yield was not significantly increased under NT. There were however slight interannual variations in yield response to treatments. Grain yields were generally higher in 2018 than in 2017. Also in 2017 NTS showed the highest grain yield but in 2018 CTS showed the highest grain yield. While only NTS significantly increased grain yield in 2017, in 2018 both NTS and CTS significantly improved grain yield.

\section{Table 2.}

\section{Average greenhouse gas emissions}

Ecosystem Respiration for all treatments are shown in figures $4 \mathrm{a}$ and $4 \mathrm{~b}$ respectively. Tilled soils emitted significantly more $\mathrm{CO}_{2}$ than non-tilled soils. In the growing season, average $\mathrm{CO}_{2}$ emission rates were $270.475 \pm 11.03,262.88 \pm 0.20,183.83 \pm 34.05$ and $190.72 \pm 19.20 \mathrm{mg} \mathrm{C} \mathrm{m}^{-2} \mathrm{~h}^{-1}$ in CT, CTS, NT, and NTS respectively, resulting in emission reduction in CTS, NT, and NTS by $2.81 \%, 32.03 \%$ and $29.48 \%$ respectively. In the non-growing season, emissions were relatively lower at rates of $30.55 \pm 1.71,45.51 \pm 3.88,31.74 \pm 1.35$ and $34.15 \pm 5.71 \mathrm{mg} \mathrm{C} \mathrm{m}^{-2} \mathrm{~h}^{-1}$ respectively in CT, CTS, NT, and NTS.

All the treatments served as minor sinks of $\mathrm{CH}_{4}$ (Fig. 4c,d). The respective absorption rates were $-0.071 \pm 0.041,-0.102 \pm 0.005,-0.106 \pm 0.009$ and $-0.149 \pm 0.001 \mathrm{mg} \mathrm{C} \mathrm{m}^{-2} \mathrm{~h}^{-1}$ for CT, CTS, NT and NTS in the growing season while in the non-growing season the values were $0.081 \pm 0.064,-0.055 \pm 0.006,-0.071 \pm 0.018$ and $-0.055 \pm 0.004 \mathrm{mg} \mathrm{C} \mathrm{m}^{-2} \mathrm{~h}^{-1}$ respectively. However, there were variations in their sink capacities. NTS was the largest sink in the growing season while CT was the largest sink in the non-growing season. Generally, average absorption rates were higher in the growing season than in the non-growing season in all treatments except CT.

Averagely across seasons, all treatments served as emitters of $\mathrm{N}_{2} \mathrm{O}$, but flux values were statistically similar under all treatments in both seasons. Also, there were higher emissions in the growing season than the non-growing season (Fig. 4 e, f). In the growing season, CTS had the highest emission of $\mathrm{N}_{2} \mathrm{O}$. The fluxes in the growing season were $3.09 \pm 1.96,14.88 \pm 0.42$, $11.39 \pm 6.80$ and $12.61 \pm 2.76 \mu \mathrm{g} \mathrm{N} \mathrm{m}^{-2} \mathrm{~h}^{-1}$ for CT, CTS, NT and NTS respectively while in the non-growing season, values of $\mathrm{N}_{2} \mathrm{O}$ fluxes ranged between 0.21 and $2.69 \mu \mathrm{g} \mathrm{N} \mathrm{m}^{-2} \mathrm{~h}^{-1}$.

\section{Fig. 4}




\section{Net GHG fluxes, Global warming potential (GWP) and Greenhouse 267 Gas Intensity (GHGI)}

268

269

270

271

272

273

274

275

276

277

278

279

280

281

282

283

284

285

286

287

288

289

290

291

292

293

294

295

296

297

298

299

300

301

302

The Net $\mathrm{CO}_{2}$-flux, $\mathrm{CO}_{2}$ equivalents $\left(\mathrm{CO}_{2} \mathrm{e}\right)$ of $\mathrm{CH}_{4}$ and $\mathrm{N}_{2} \mathrm{O}$, GWP and GHGI of all treatments are shown in Table 3. Grain Yield (Table 1) and Harvest index were used to estimate the carbon components of harvest i.e. grain and straw in order to obtain Gross Primary production (GPP) and Net Primary Production (NPP). Harvest index, carbon in grain and straw, GPP and NPP are shown in supplemental file 2.

Net $\mathrm{CO}_{2}$ fluxes in NTS and NT $\left(6.65 \pm 0.73\right.$ and $7.37 \pm 0.89 \mathrm{tCO}_{2} \mathrm{e} \mathrm{ha}^{-1} \mathrm{y}^{-1}$ respectively) were significantly lower than those in CT and CTS $\left(11.14 \pm 0.58\right.$ and $10.65 \pm 0.18 \mathrm{tCO}_{2} \mathrm{e} \mathrm{ha}^{-1} \mathrm{y}^{-1}$ respectively), showing reduced net carbon exchange into the atmosphere under NTS and NT. Similarly, GWP was greater in CT than all other treatments with significant reductions in NT and NTS $(p<0.05)$. Compared with CT, the reduction in GWP was $2.83 \%, 33.40 \%$, and $40.35 \%$ under CTS, NT and NTS respectively. The GHGI is a yield-scale quantification of GWP, thus is a factor of GWP and Grain yield. It shows the contribution of the cropping system to global warming per unit grain yield. Our results showed that CT was the highest contributor of global warming per unit grain produced compared with other treatments. Significant reductions of GHGI were found in NTS and NT $(\mathrm{p}<0.05)$.

\section{Table 3}

\section{Correlations between Soil parameters and Grain Yield}

Grain yields were highly influenced by soil nutrients. There were significant positive correlations $(\mathrm{p}<0.05)$ of grain yield and SOC and STN (Table 4) at the $0-10 \mathrm{~cm}$ and $10-20 \mathrm{~cm}$ depths respectively (Table 4$)$. However at deeper depths $(20-40 \mathrm{~cm})$, there were no significant correlations observed.

\section{Table 4}

\section{Correlations between ST, SWC and Greenhouse gases}

Greenhouse gas fluxes were generally influenced by ST and SWC as shown in Table 5. $\mathrm{CO}_{2}$ emission in the form of ecosystem respiration $\left(\mathrm{R}_{\text {eco }}\right)$ increased exponentially as $\mathrm{ST}$ increased; ST- $\mathrm{R}_{\text {eco }}$ relationship followed an exponential function and was highly significant $(\mathrm{p}<0.001)$ and positive with $\mathrm{R}^{2}$ values of $0.68,0.63,0.80$ and 0.80 respectively in CT, CTS, NT and NTS while SWC-R $R_{\text {eco }}$ relationship was best described by a power function and also showed highly significant $(\mathrm{p}<0.001)$ positive correlations with $\mathrm{R}^{2}$ values of $0.06,0.10,0.14$ and 0.07 respectively in CT, CTS, NT and NTS. Similarly, for $\mathrm{CH}_{4}$ fluxes, ST- $\mathrm{CH}_{4}$ relationship was an exponential function and highly significant as well $(\mathrm{p}<0.001)$ while $\mathrm{SWC}-\mathrm{CH}_{4}$ relationship was 
303

304

305

306

307

308

309

310

311

312

313

314

315

316

317

318

319

320

321

322

323

324

325

326

327

328

329

330

331

332

333

334

335

336

337

338

339

340

341

342

best described by a linear function, albeit not significant. Meanwhile ST and SWC did not seem to explain variations of $\mathrm{N}_{2} \mathrm{O}$ as the correlations were not significant except in ST- $\mathrm{N}_{2} \mathrm{O}$ relationship under CTS.

\section{Table 5}

\section{Discussion}

Increased SWC and ST reduction in NTS (Fig 2) is in line with other studies where conservation tillage improved SWC and soil water storage (Lal et al., 2012; Li et al., 2014). This could be attributed to the effect of straw (He et al., 2011; Lal et al., 2012). Straw reduced evaporation (Kang et al. 2004) leading to improvement in water retention (Hill et al., 1985) and infiltration (Li et al 2011b). Straw mulch may also insulate the soil from direct impact of solar heat leading to decline of temperature.

Other studies have also reported increased SOC stocks after adoption of conservation tillage practices (Ogle et al., 2005; Paustian et al., 2006) which is similar to the findings of this study. Increased SOC and STN in CA plots could be attributed to less disturbance of soil which might reduce the risk of exposure of soil organic matter to decomposition process, thereby increasing SOC storage (Lal, 2015; Reicosky, 1997; Six et al., 2000). Also, favorable moisture content in CA plots (fig. 2) may foster water and nutrient uptake by plant roots and also induce substrate movement for $\mathrm{C}$ fixation which may result in higher photosynthetic $\mathrm{C}$ input, leading to net $\mathrm{C}$ sequestration. Soil moisture and residue retention in CA plots may reduce wind and water erosion which could improve soil water storage and reduce leaching of soil nitrogen (Allmaras and Dowdy, 1985; Lamb et al., 1985).

Higher grain yield under CA practices (Table 1) is in tandem with other studies where conservation tillage increased grain yields (Bordovsky et al., 1998; Halvorson et al., 2000; Li et al., 2014; Zheng et al. 2014; Yeboah et al., 2016 a,b). This could be attributed to improved soil properties under these treatments. Higher SWC (Fig. 2) facilitated movement and uptake of available nutrients, as shown by higher SOC and STN stocks in NTS, NT and CTS (Fig 3) thereby leading to higher grain yields. This plausibility is increased as Pearson correlation showed significant positive correlations between grain yield and these soil properties (Table 3 ).

Significant lower rates of ecosystem respiration $(p<0.05)$ in NT and NTS compared with the tilled soils (Fig. 4) was consistent with other studies (Chaplot et al., 2012; Yeboah et al., 2016b) where conservation tillage significantly reduced soil respiration. $\mathrm{CO}_{2}$ emission rates is often controlled by a number of factors including: gradient of concentration of $\mathrm{CO}_{2}$ between the atmosphere and the soil medium, soil water, soil temperature, wind speed and soil physical and chemical properties (Raich \& Schlensinger, 1992). Tillage influences these factors directly and or indirectly which resultantly influences $\mathrm{CO}_{2}$ emissions as well. Soil disturbance under conventional tillage, may trigger microbial activities and increase decomposition rates (Alkaisi \& Yin, 2005), leading to higher $\mathrm{CO}_{2}$ emissions. Soil disturbance may also increase soil aeration, resulting in higher oxidation of carbon into $\mathrm{CO}_{2}$ (Jackson et al., 2003). On the contrary, under

Peer] reviewing PDF | (2019:10:42209:2:0:NEW 28 Jan 2021) 
343 no-till, decomposition is slower due to less soil disturbance (Curtin et al., 2000). Higher soil 344 temperature under CT (Fig 2) may exponentially increase microbial activities (Meixner, 2006) 345 while lower soil temperature may reduce microbial activity, hence reduce emissions in the 346 conservation tillage plots (Carbonell-Bojollo et al., 2012). This corroborates with the significant 347 positive relationship between soil temperature and ecosystem respiration found in this study 348 (Table 4).

349 All four tillage methods resulted in uptake of $\mathrm{CH}_{4}$ in both growing and non-growing seasons. 350 Other studies on the Loess Plateau obtained similar results (Wan et al., 2009; Yeboah et al., 351 2016b). Shen et al. (2018) indicated that agroecosystems in dry regions with minimal irrigation

352 often act as $\mathrm{CH}_{4}$ sinks due to aerobic soil conditions. This is due to oxidation of $\mathrm{CH}_{4}$ under 353 aerobic conditions (Matson et al., 2009; Schaufler et al., 2010). Lower temperatures under NTS may have played significant role in high uptake of $\mathrm{CH}_{4}$ in NTS. The dominant methanogen

355

356

357

358

359

360

361

362

363

364

365

366

367

368

369

370

371

372

373

374

375

376

377

378

379

380

381

382 during high temperatures (Methanosarcinaceae) utilizes $\mathrm{H}_{2} / \mathrm{CO}_{2}$ and acetate as methane producing precursors, and produces far higher methane than the methanogen at lower temperatures (Methanosaetaceae), which uses only acetate as methane producing precursor (Ding \& Cai, 2003).

Average $\mathrm{N}_{2} \mathrm{O}$ fluxes found in this study were in the range of fluxes reported by Ma et al. (2013) in their study of GHGs in a rice-wheat rotation under integrated crop management systems. Averagely, all treatments served as slight emitters of $\mathrm{N}_{2} \mathrm{O}$ (Fig. 4). This is also consistent with the study of Yeboah et al. (2016b) on the Loess Plateau. There was significant positive correlation between soil temperature and $\mathrm{N}_{2} \mathrm{O}$ emission in CTS. Higher temperatures and soil water content in the growing season where $70-80 \%$ of rainfall occurs (Fig 1) may have triggered nitrification and denitrification processes (Davidson \& Swank, 1986), leading to higher $\mathrm{N}_{2} \mathrm{O}$ emissions in this season. High rainfall may increase water filled pore space, which influences $\mathrm{N}_{2} \mathrm{O}$ emissions in agricultural soils (Dobbie \& Smith, 2003). Trujillo et al. (2008) also reported positive correlation of $\mathrm{N}_{2} \mathrm{O}$ with soil temperature and soil water content. Higher emission in the growing season than in the non-growing season could also be related to fertilizer $\mathrm{N}$ application in the growing season and its interactive effect with wet conditions within this period on denitrification processes (Cho et al., 1997).

The GWPs (Table 2) were in the range as reported by Ma et al. (2013) but greater than those reported by Yeboah et al. (2016b). Furthermore, GHGIs in this study were far higher than those found in other studies (Qin et al., 2010; Ma et al., 2013). Higher GWPs and GHGIs in this study could be attributed to a general lower grain yield (Table 1) which is typically associated with drylands. Lower grain yield may generally result in relatively low carbon input (Supplementary file 2) which may in turn result in relatively higher net GHG emissions. However GWP being lower under NT and NTS than in CT and CTS is attributable to relatively higher carbon input from the above ground plant product coupled with lower ecosystem respiration and higher $\mathrm{CH}_{4}$ uptake in these plots.

PeerJ reviewing PDF | (2019:10:42209:2:0:NEW 28 Jan 2021) 


\section{Conclusions}

384

385

386

387

388

389

390

391

392

393

394

395

396

397

398

399

400

401

402

403

404

405

406

407

408

409

410

411

412

413

414

415

416

417

418

419

420

421

422
This study hypothesized that no-till and the application of straw improved soil chemical and physical properties, increased crop yield and reduced greenhouse gas emissions by comparing 3 conservation practices [conventional tillage with straw (CTS), No-till (NT) and no-till with straw (NTS)] to conventional tillage (CT). Our study showed that conservation tillage practices especially NTS improved soil water content and reduced soil temperature. Soil organic carbon and total nitrogen were also significantly improved under conservation practices especially within the top soil layer $(0-20 \mathrm{~cm})$. There was also significant improvement in average grain yield under NTS and CTS. Conservation tillage further reduced net $\mathrm{CO}_{2}$ flux; increased $\mathrm{CH}_{4}$ absorption but only slightly influenced $\mathrm{N}_{2} \mathrm{O}$ emissions in the dryland ecosystem. NTS and NT significantly reduced GWP and yield-scale GWP. For sustainability of arid and semi-arid cropping systems and for environmental quality we recommend the adoption of conservation agricultural practices such as no-till, straw mulch, green manuring, contour ploughing and terracing on the Loess Plateau. Furthermore crop genetic and breeding techniques such as the use of drought resistant crop varieties should also be explored in order to enhance climate change resilience of crop production in dryland areas and reduce climate footprint of these areas.

(1)




\section{References}

424 Alhassan ARM, Ma W, Li G, Jiang Z, Wu J, Chen G. 2018. Response of soil organic carbon

425

426

427

428

429

430

431

432

433

434

435

436

437

438

439

440

441

442

443

444

445

446

447

448

449

450

451

452

453

454

455

456

457

458

459

460

461

462 to vegetation degradation along a moisture gradient in a wet meadow on the Qinghai-Tibet Plateau. Ecology \& Evolution 8(23): 11999-12010.

Al-Kaisi MM, Yin X. 2005. Tillage and crop residue effects on soil carbon and carbon dioxide emission in corn-soybean rotations. Journal of Environmental Quality 34(2): 437-445.

Allmaras RR, Dowdy RH. 1985. Conservation tillage and their adoption in the United States. Soil Tillage Research 5(2): 197-222.

An P, Inoue T, Zheng M, Eneji AE, Inanaga S. 2014. Agriculture on the Loess Plateau. In Restoration and development of the degraded Loess Plateau, China, ed. Tsunekawa A, Liu G, Yamanaka N, Du S, 61-74. Japan: Springer.

Bolinder MA., Janzen HH, Gregorich EG, Angers DA, Vanden Bygaart AJ. 2007. An approach for estimating net primary productivity and annual carbon inputs to soil for common agricultural crops in Canada. Agriculture, Ecosystems \& Environment 118(1-4): 29-42.

Bordovsky DG, Choudhary M, Gerard C J. 1998. Tillage effects on grain sorghum and wheat yields in the Texas Rolling Plains. Agronomy journal 90(5): 638-643.

Bouwman AF. 1996. Direct emission of nitrous oxide from agricultural soils. Nutrient Cycling in Agroecosystems 46(1): 53-70.

Bremner JM, Mulvaney CS. 1982. Nitrogen-total. In A. L. Page et al., (Eds), Methods of Soil Analysis Part 2 (pp. 595-624).Madison, Wisconsin: American Society of Agronomy

Calzadilla A, Rehdanz K, Betts R, Falloon P, Wiltshire A, Tol R. S. 2013. Climate change impacts on global agriculture. Climatic change 120(1-2): 357-374.

Carbonell-Bojollo RM, de Torres MARR, Rodríguez-Lizana A, Ordóñez-Fernández R.

2012. Influence of soil and climate conditions on $\mathrm{CO}_{2}$ emissions from agricultural soils. Water, Air, \& Soil Pollution 223(6): 3425-3435.

Chaplot V, Mchunu CN, Manson A, Lorentz S, Jewitt G. 2012. Water erosion-induced $\mathrm{CO}_{2}$ emissions from tilled and no-tilled soils and sediments. Agriculture, ecosystems \& environment 159: 62-69.

Cho C M, Burton D L, Chang C. 1997. Denitrification and fluxes of nitrogenous gases from soil under steady oxygen distribution. Canadian Journal of Soil Science 77(2): 261-269.

Cole CV, Duxbury J, Freney J, Heinemeyer O, Minami K, Mosier A, Paustian K, Rosenberg N, Sampson N, Sauerbeck D, Zhao Q. 1997. Global estimates of potential mitigation of greenhouse gas emissions by agriculture. Nutrient cycling in Agroecosystems 49(13): 221-228.

Curtin D, Wang H, Selles F, McConkey BG, Campbell CA. 2000. Tillage effects on carbon fluxes in continuous wheat and fallow-wheat rotations. Soil Science Society of America Journal 64(6): 2080-2086.

Davidson EA, Swank WT. 1986. Environmental parameters regulating gaseous nitrogen losses from two forested ecosystems via nitrification and denitrification. Applied \& Environmental Microbiology 52(6): 1287-1292. 
463 Ding W, Cai Z. 2003. Effect of temperature on methane production and oxidation in soils. Ying

464

465

466

467

468

469

470

471

472

473

474

475

476

477

478

479

480

481

482

483

484

485

486

487

488

489

490

491

492

493

494

495

496

497

498

499

500

501

502

yong sheng tai xue bao= The journal of applied ecology 14(4): 604-608.

Dobbie KE, Smith KA. (2003). Nitrous oxide emission factors for agricultural soils in Great Britain: the impact of soil water-filled pore space and other controlling variables. Global change biology, 9(2): 204-218.

Fabrizzi KP, Garcia FO, Costab JL, Picone LI. 2005. Soil water dynamics, physical properties and corn and wheat responses to reduced and no-tillage systems in the southern Pampas of Argentina. Soil Tillage Research 81: 57-69.

Halvorson AD, Black AL, Krupinsky JM, Merrill SD, Wienhold BJ, Tanaka DL. 2000. Spring wheat response to tillage and nitrogen fertilization in rotation with sunflower and winter wheat. Agronomy journal 92(1): 136-144.

He J, Li H, Rasaily RG, Wang Q, Cai G, Su Y, Qiao X, Liu L. 2011. Soil properties and crop yields after 11 years of no tillage farming in wheat-maize cropping system in North China Plain. Soil and Tillage Research 113(1): 48-54.

Hill R L, Horton R, Cruse RM. 1985. Tillage effects on soil water retention and pore size distribution of two mollisols. Soil Science Society of America Journal 49(5): 1264-1270.

Huang M, Dang T, Gallichand J, Goulet M. 2003. Effect of increased fertilizer applications to wheat crop on soil-water depletion in the Loess Plateau, China. Agricultural Water Management 58 (3): 267-278.

Huang Y, Zhang W, Sun W, Zheng X. 2007. Net primary production of Chinese croplands from 1950 to 1999. Ecological Applications 17(3): 692-701.

Indoria AK, Sharma KL, Reddy KS, Rao CS. 2016. Role of soil physical properties in soil health management and crop productivity in rainfed systems-II. Management technologies and crop productivity. Current Science 110(3): 320.

IPCC. 2007. Climate change 2007: Impacts, adaptation and vulnerability. Contribution of Working Group II to the Fourth Assessment Report of the IPCC. Parry ML, Canziani OF, Palutikof JP, van der Linden PJ, Hanson CE (eds) Cambridge University Press, Cambridge, UK, pp. 976

Jackson LE, Calderon FJ, Steenwerth KL, Scow KM, Rolston DE. 2003. Responses of soil microbial processes and community structure to tillage events and implications for soil quality. Geoderma 114(3-4): 305-317.

Kang S, Su X, Tong L, Shi P, Yang X, Abe Y, Du T, Shen Q, Zhang J. 2004. The impacts of human activities on the water-land environment of the Shiyang River basin, an arid region in northwest China/Les impacts des activités humaines sur l'environnement pédo-hydrologique du bassin de la Rivière Shiyang, une région aride du nord-ouest de la Chine. Hydrological Sciences Journal 49(3).

Lal R. 2005. Climate change, soil carbon dynamics, and global food security. In Climate change and global food security (pp. 113-143). Boca Raton, FL, Taylor and Francis.

Lal R. 2015. Sequestering carbon and increasing productivity by conservation agriculture.

Journal of Soil \& Water Conservation 70(3): 55A-62A.

Peer] reviewing PDF | (2019:10:42209:2:0:NEW 28 Jan 2021) 
503 Lal R, Delgado JA, Gulliford J, Nielsen D, Rice CW, Van Pelt RS. 2012. Adapting

504

505

506

507

508

509

510

511

512

513

514

515

516

517

518

519

520

521

522

523

524

525

526

527

528

529

530

531

532

533

534

535

536

537

538

539

540

541

542

agriculture to drought and extreme events. Journal of Soil \&Water Conservation 67(6): 162A166A.

Lamb JA, Peterson GA, Fenster CR. 1985. Wheat fallow tillage systems' effect on a newly cultivated grassland soils' nitrogen budget. Soil Science Society of America Journal 49 (2): 352 356.

Lampurlanés J, Angas P, Cantero-Martinez C. 2002. Tillage effects on water storage during fallow, and on barley root growth and yield in two contrasting soils of the semi-arid Segarra region in Spain. Soil Tillage Research 65 (2): 207-220.

Li H, Zhou Y, Xin W, Wei Y, Zhang J, Guo L. 2019. Wheat breeding in northern China: achievements and technical advances. The Crop Journal 7(6): 718-729.

Li L, Huang G, Zhang R, Bill B, Guangdi L, Kwong YC. 2011. Benefits of conservation agriculture on soil and water conservation and its progress in China. Agricultural Sciences in China 10(6): 850-859.

Li L, Zhang R, Luo Z, Liang W, Xie J, Cai L, Bellotti B. 2014. Evolution of soil and water conservation in rain-fed areas of China. International Soil \& Water Conservation Research 2(1): 78-90.

Ma YC, Kong XW, Yang B, Zhang XL, Yan XY, Yang JC, Xiong ZQ. 2013. Net global warming potential and greenhouse gas intensity of annual rice-wheat rotations with integrated soil-crop system management. Agriculture, ecosystems \& environment 164: 209-219.

Matson A, Pennock D, Bedard-Haughn A. 2009. Methane and nitrous oxide emissions from mature forest stands in the boreal forest, Saskatchewan, Canada. Forest Ecology \& Management 258(7): 1073-1083. Doi:10.1016/j.foreco.2009.05.034.

Meixner FX. 2006. Biogenic emissions of nitric oxide and nitrous oxide from arid and semi-arid land. In Dryland ecohydrology (pp. 233-255). Springer, Dordrecht.

Nelson DW, Sommers LW.1982. Total carbon, organic carbon and organic matter. In: AL Page et al. (eds). Methods of soil analysis Part 2 (Second edition). Chemical and microbiological properties (pp 301-312). Wisconsin/Madison USA: American Society of Agronomy and Soil Science Society of American Journal.

Ogle SM, Breidt FJ, Paustian K. 2005. Agricultural management impacts on soil organic carbon storage under moist and dry climatic conditions of temperate and tropical regions. Biogeochemistry 72(1): 87-121.

Paustian K, Antle JM, Sheehan J, Paul EA. 2006. Agriculture's role in greenhouse gas mitigation. Arlington (VA) Canada, Pew Center on Global Climate Change.

Pittelkow CM, Liang X, Linquist BA, van Groenigen K J, Lee J, Lundy ME, Van Gestel N, Six J, Venterea RT, van Kessel C. 2015. Productivity limits and potentials of the principles of conservation agriculture. Nature 517(7534): 365-368.

Qin Y, Liu S, Guo Y, Liu Q, Zou J. 2010. Methane and nitrous oxide emissions from organic and conventional rice cropping systems in Southeast China. Biology \& Fertility of Soils 46(8): $825-834$.

Peer) reviewing PDF | (2019:10:42209:2:0:NEW 28 Jan 2021) 
543 Raich JW, Schlesinger WH. 1992. The global carbon dioxide flux in soil respiration and its 544 relationship to vegetation and climate. Tellus B 44(2): 81-99.

545 Reicosky DC. 1997. Tillage-induced $\mathrm{CO}_{2}$ emission from soil. Nutrient cycling in

546 agroecosystems 49(1-3): 273-285.

547 Schaufler G, Kitzler B, Schindlbacher A, Skiba U, Sutton MA, Zechmeister-Boltenstern S.

548 2010. Greenhouse gas emissions from European soils under different land use: effects of soil

549 moisture and temperature. European Journal of Soil Science 61(5): 683-696. doi:10.1111/j.1365-

$550 \quad 2389.2010 .01277 . x$

551 Shen Y, Sui P, Huang J, Wang D, Whalen JK, Chen Y. 2018. Greenhouse gas emissions

552 from soil under maize-soybean intercrop in the North China Plain. Nutrient cycling in

553 agroecosystems 110(3): 451-465.

554 Six JAET, Elliott ET, Paustian K. 2000. Soil macroaggregate turnover and microaggregate

555 formation: a mechanism for $\mathrm{C}$ sequestration under no-tillage agriculture. Soil Biology \&

556 Biochemistry 32(14): 2099-2103.

557 Smith P, Fang C, Dawson JJ, Moncrieff JB. 2008. Impact of global warming on soil organic

558 carbon. Advances in agronomy 97: 1-43.

559 Taa A, Tanner D, Bennie ATP. 2004. Effects of stubble management, tillage and cropping

560 sequence on wheat production in the south-eastern highlands of Ethiopia. Soil Tillage Research

561 76: $69-82$

562 Trujillo-Tapia N, Mondragón CC, Vásquez-Murrieta MS, Van Cleemput O, Dendooven L.

563 2008. Inorganic $\mathrm{N}$ dynamics and $\mathrm{N}_{2} \mathrm{O}$ production from tannery effluents irrigated soil under

564 different water regimes and fertilizer application rates: A laboratory study. Applied soil ecology

565 38(3): 279-288.

566 Wan YF, Li YE, Gao QZ, Qin XB, Lin ED. 2009. Field managements affect yield, soil carbon,

567 and greenhouse gases emission of winter wheat in North China Plain. Journal of Agro-

568 Environment Science 12.

569 Wang Q, Bai Y, Gao H, He J, Chen H, Chesney RC, Kuhn NJ, Li H. 2008. Soil chemical

570 properties and microbial biomass after 16 years of no-tillage farming on the Loess Plateau,

571 China. Geoderma 144(3-4): 502-508.

572 Wang YS, Wang YH. 2003. Quick measurement of CH4, CO2 and N2O emission from a short

573 plant ecosystem. Advances in Atmospheric Sciences 20: 842-844.

574 Wei D, Liu Y, Wang YS, Wang YH. 2014. Three-year study of $\mathrm{CO}_{2}$ efflux and $\mathrm{CH}_{4} / \mathrm{N}_{2} \mathrm{O}$ fluxes

575 at an alpine steppe site on the central Tibetan Plateau and their responses to simulated $\mathrm{N}$

576 deposition. Geoderma 232: 88-96.

577 Woźniak A, Gos M. 2014. Yield and quality of spring wheat and soil properties as affected by

578 tillage system. Plant, Soil and Environment 60(4): 141-145.

579 Yeboah S, Zhang R, Cai L, Li L, Xie J, Luo Z, Liu J, Wu J. 2016a. Tillage effect on soil

580 organic carbon, microbial biomass carbon and crop yield in spring wheat-field pea rotation.

581 Plant, Soil \& Environment 62(6): 279-285. 
582 Yeboah S, Zhang R, Cai L, Song M, Li L, Xie J, Luo Z, Wu J, Zhang J. 2016b. Greenhouse 583 gas emissions in a spring wheat-field pea sequence under different tillage practices in semi-arid 584 Northwest China. Nutrient Cycling in Agroecosystems 106(1): 77-91.

585 Zhang Y, Xu M, Chen H, Adams J. 2009. Global pattern of NPP to GPP ratio derived from

586 MODIS data: effects of ecosystem type, geographical location and climate. Global Ecology and 587 Biogeography 18(3): 280-290.

588 Zheng C, Jiang Y, Chen C, Sun Y, Feng J, Deng A, Song Z, Zhang W. 2014. The impacts of 589 conservation agriculture on crop yield in China depend on specific practices, crops and cropping 590 regions. The Crop Journal 2(5): 289-296.

591

592

593

594

595

596

597

598

599

600 
Figure 1

Rainfall amounts for 2017 (a), 2018 (b) and Mean, maximum and minimum temperatures for 2017 (c) and 2018 (d) in the Anjiapo catchment in Dingxi

Rainfall amounts for 2017 (a), 2018 (b) and Mean, maximum and minimum temperatures for 2017 (c) and 2018 (d) in the Anjiapo catchment in Dingxi

2017
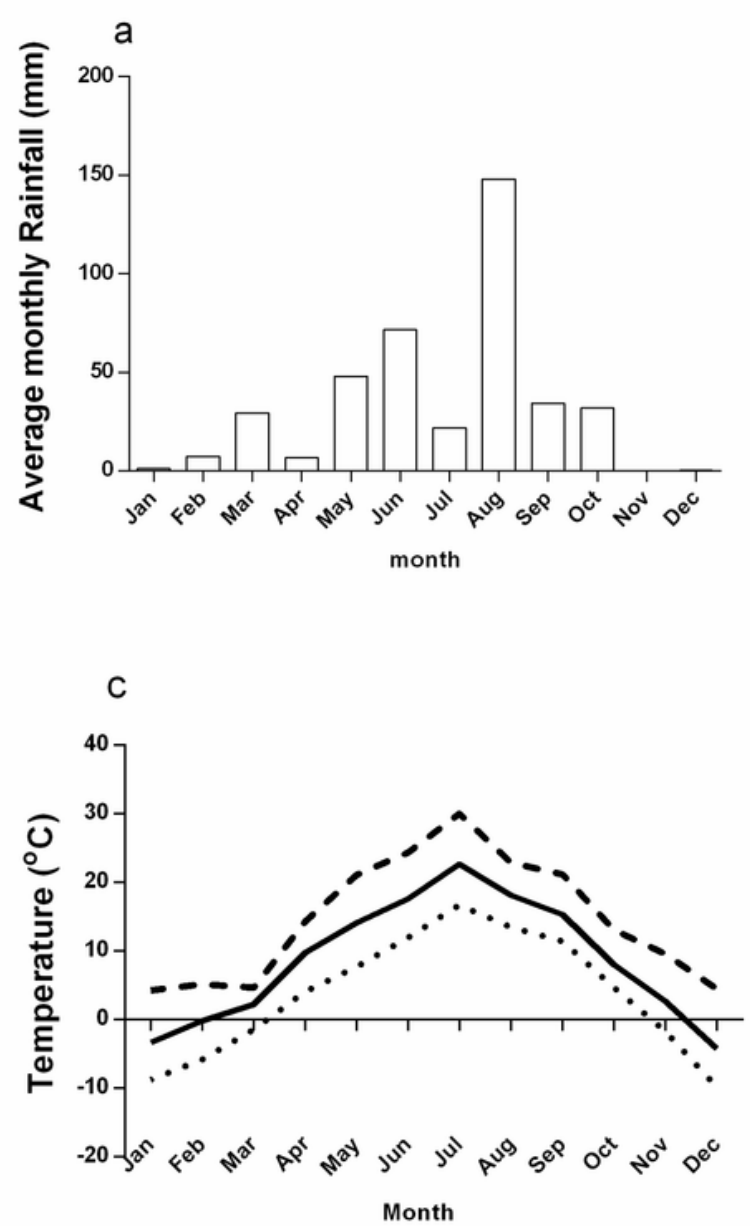

2018

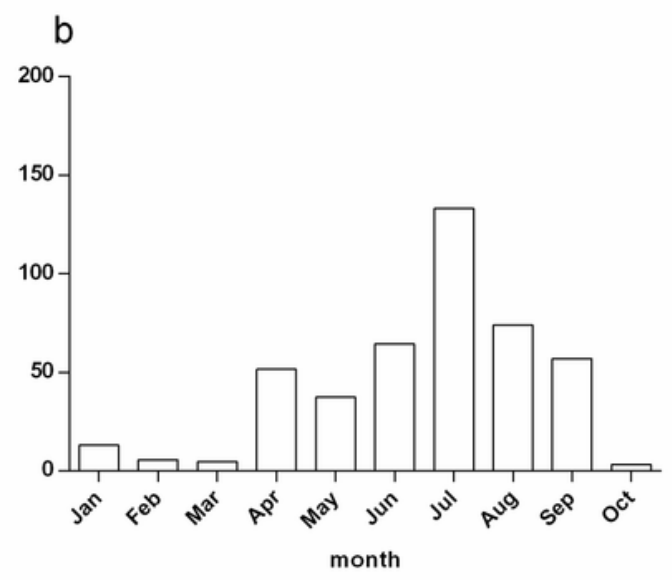

d

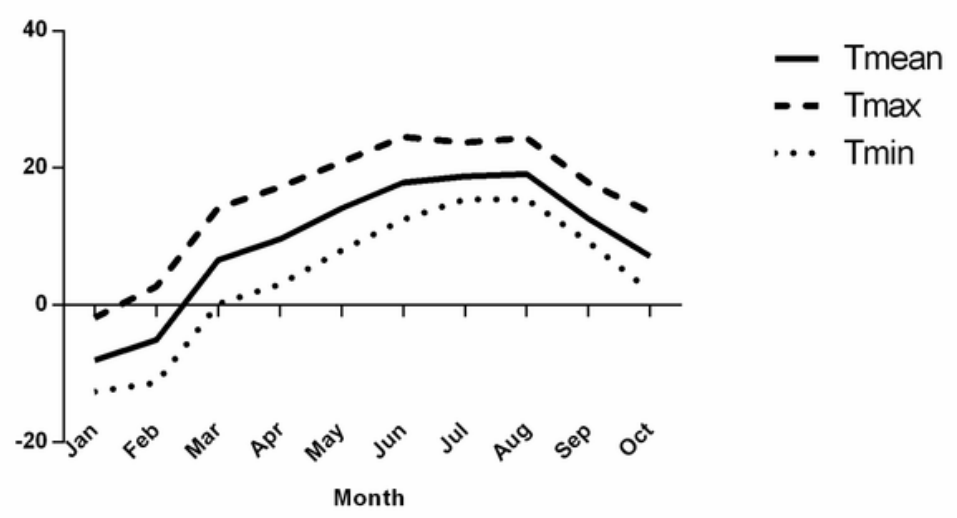


Figure 2

Soil water content (a) and soil temperature (b) at various sampling times (10 cm depth)

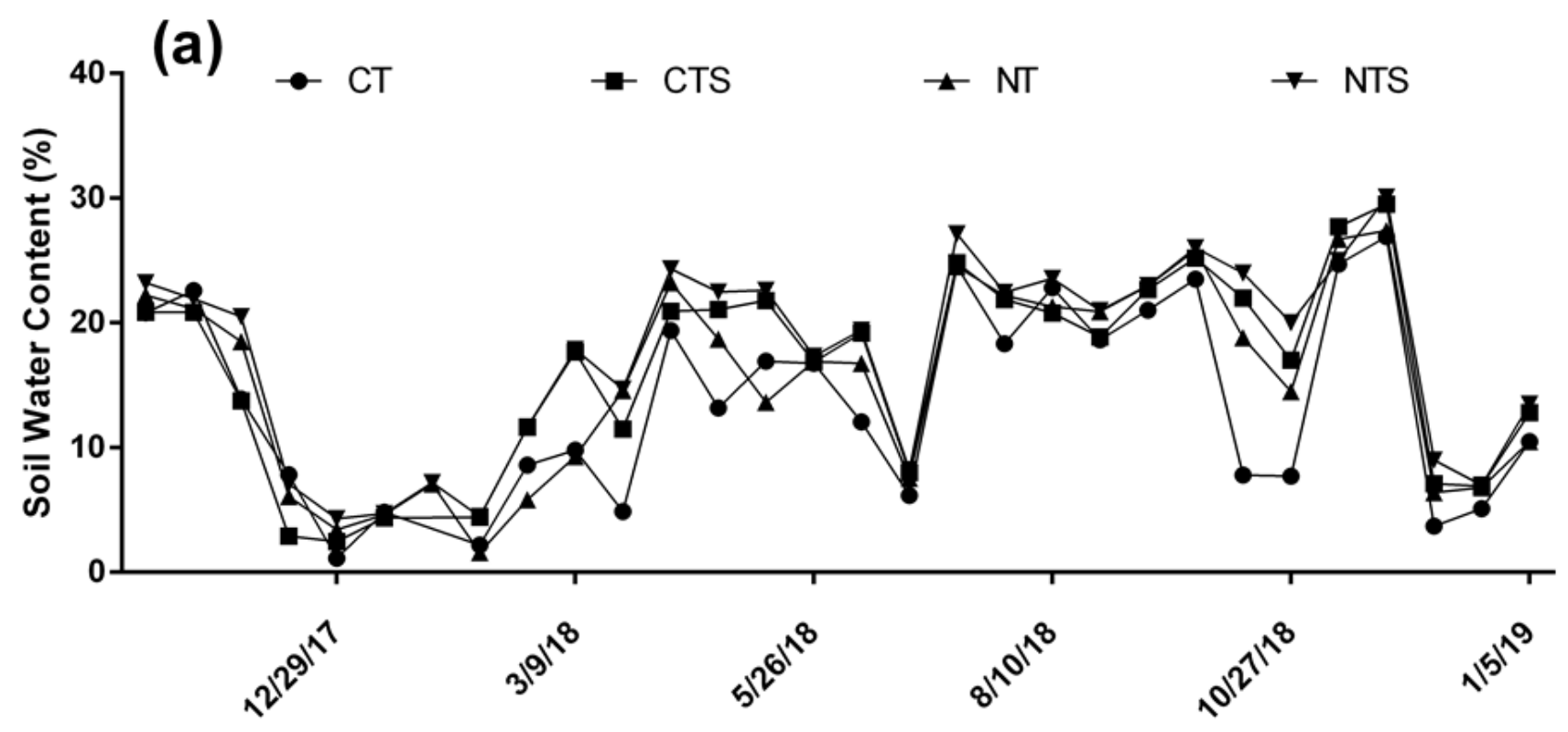

Sampling date

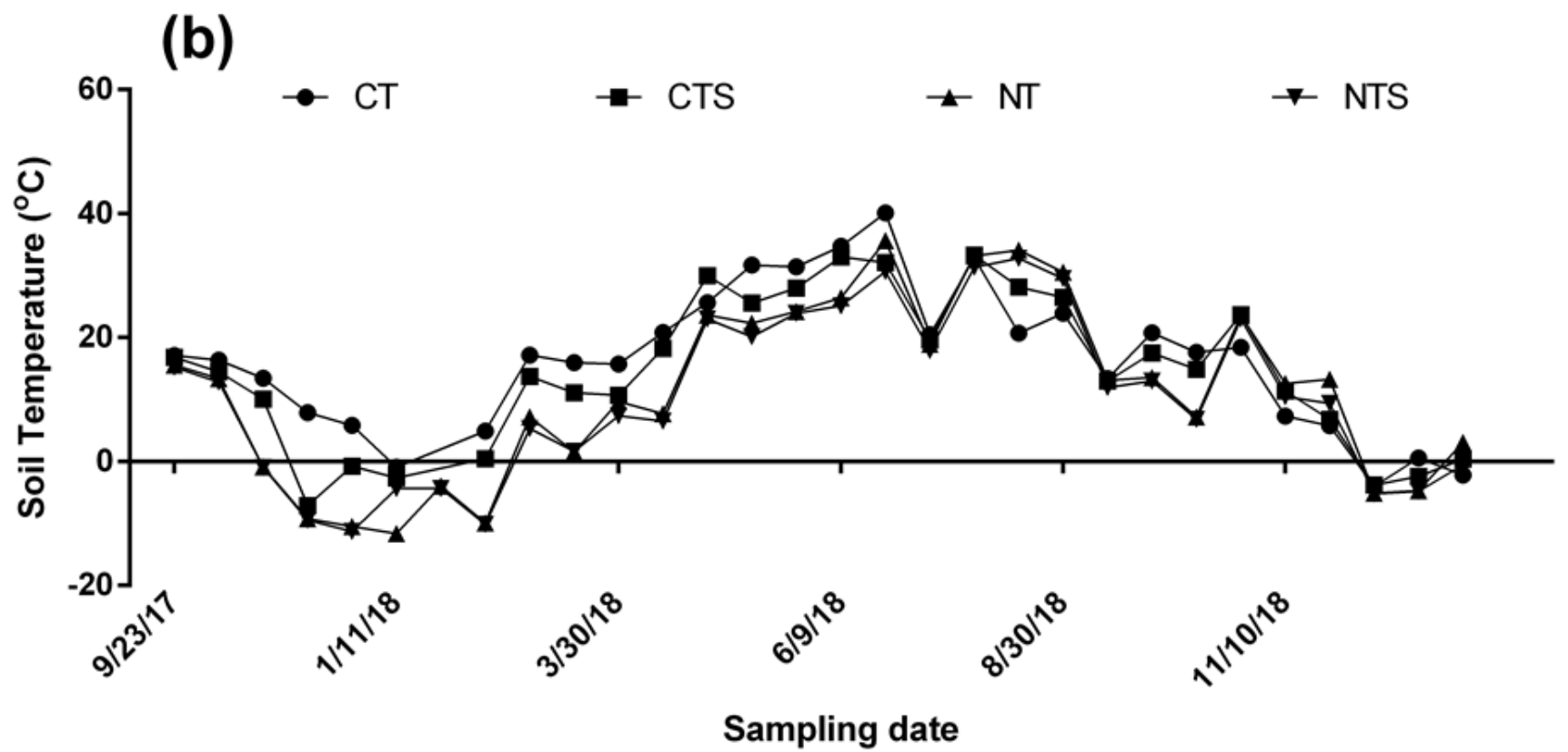


Figure 3

Soil organic carbon (SOC) and soil total nitrogen (STN) among tillage treatments within different depths.

Treatments with common letters within a depth are not statistically different at $p \leq 0.05$

(a) SOC at $0-10 \mathrm{~cm}$ soil depth

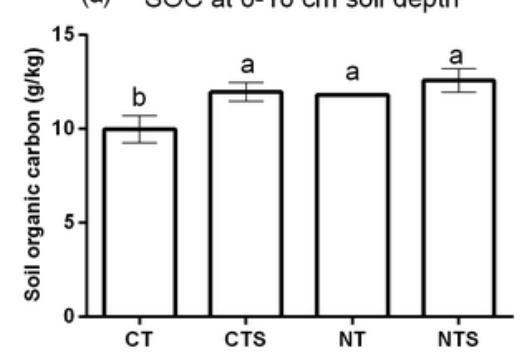

(d) STN at $0-10 \mathrm{~cm}$ soil depth

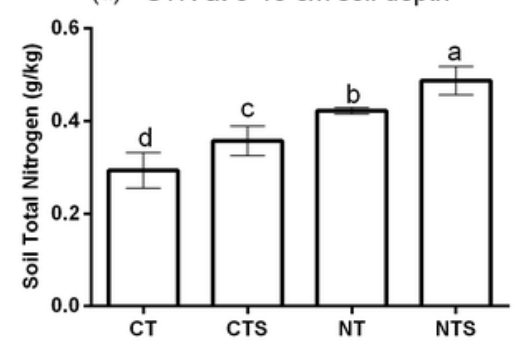

(b) SOC at $10-20$ soil depth

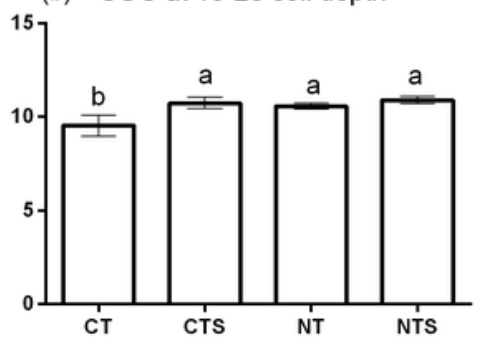

(e) STN at $10-20 \mathrm{~cm}$ soil depth

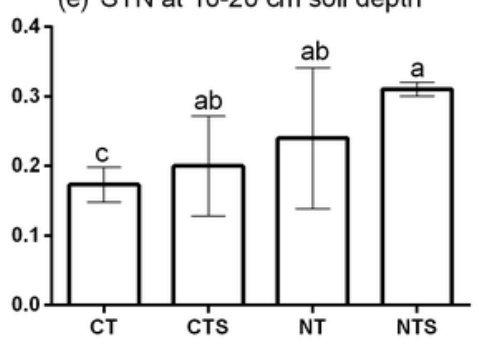

(c) SOC at $20-40 \mathrm{~cm}$ soil depth
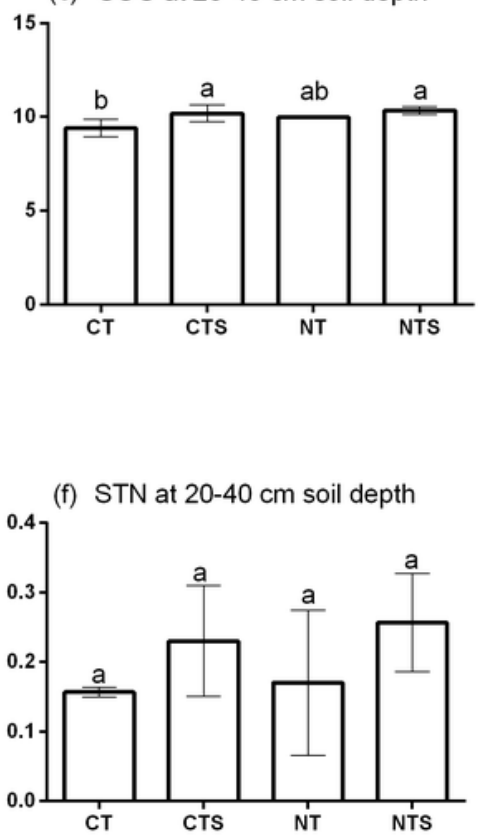
Figure 4

Average ecosystem respiration, $\mathrm{CH} 4$ and $\mathrm{N} 2 \mathrm{O}$ fluxes across treatments in growing season (a), (c) and (e) and non-growing season (b), (d) and (f).

Error bars are standard errors, $n=3$ Peer) reviewing PDF | (2019:10:42209:0:1:NEW 18 Oct 2019) Manuscript to be reviewed
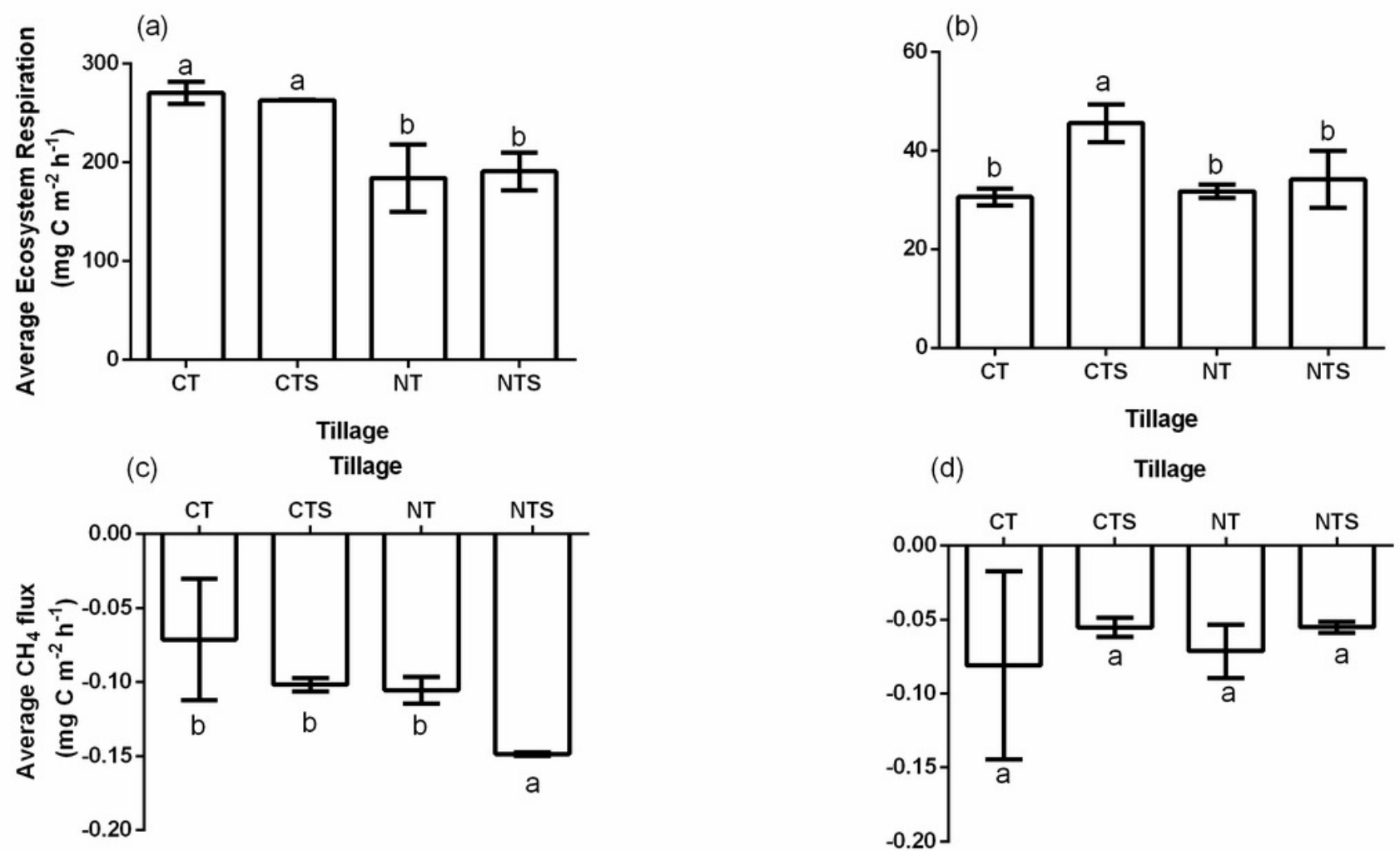

(d)

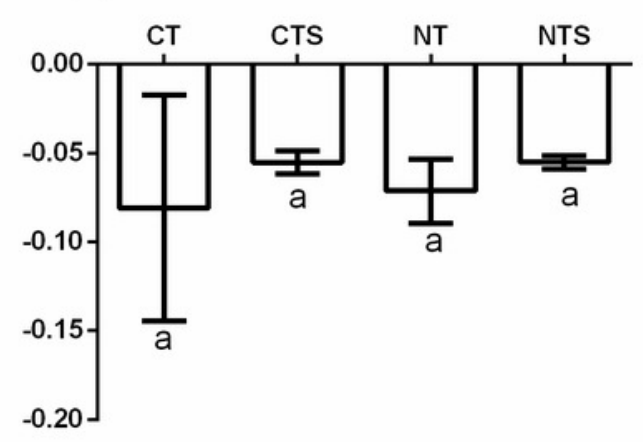

(e)

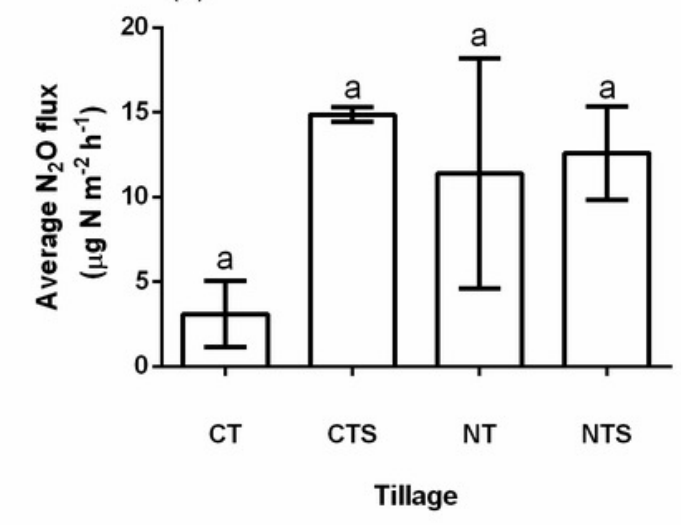

(f)

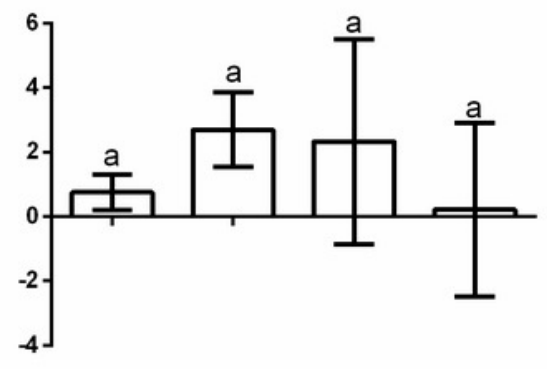

CT CTS NT NTS
Tillage 
Table $\mathbf{1}$ (on next page)

Properties of wheat Straw mulch 
1 Table 1 Properties of wheat Straw mulch

\begin{tabular}{ll}
\hline Parameter & \multicolumn{1}{c}{ Content (\%) } \\
\hline Potassium & $0.54 \pm 0.05$ \\
Carbon & $40.19 \pm 3.2$ \\
Nitrogen & $0.81 \pm 0.1$ \\
Phosphorus & $0.09 \pm 0.01$ \\
\hline
\end{tabular}

2 
Table 2 (on next page)

Wheat grain yield response to different tillage treatments 
1 Table 2 Wheat grain yield response to different tillage treatments

\begin{tabular}{llll}
\hline Treatment & $\mathbf{2 0 1 7}$ & $\mathbf{2 0 1 8}$ & $\mathbf{2 0 1 7 - 2 0 1 8}$ \\
\cline { 2 - 4 } & Grain yield & & \\
\hline CT & $581.45 \pm 73.89^{\mathrm{b}}$ & $707.78 \pm 96.49^{\mathrm{b}}$ & $644.61 \pm 76.98^{\mathrm{c}}$ \\
CTS & $587.69 \pm 35.96^{\mathrm{b}}$ & $1121.23 \pm 54.19^{\mathrm{a}}$ & $854.46 \pm 59.02^{\mathrm{ab}}$ \\
NT & $653.36 \pm 27.25^{\mathrm{b}}$ & $745.23 \pm 134.42^{\mathrm{b}}$ & $699.30 \pm 64.88^{\mathrm{bc}}$ \\
NTS & $854.46 \pm 25.33^{\mathrm{a}}$ & $961.90 \pm 21.61^{\mathrm{ab}}$ & $908.18 \pm 22.31^{\mathrm{a}}$ \\
\hline
\end{tabular}

2 


\section{Table 3(on next page)}

Net GHG fluxes, Global warming potential and Greenhouse gas intensity among tillage treatments 
1 Table 3 Net GHG fluxes, Global warming potential and Greenhouse gas intensity among tillage 2 treatments

\begin{tabular}{|c|c|c|c|c|c|}
\hline & $\begin{array}{l}\text { Net } \mathrm{CO}_{2} \text {-flux } \\
\left(\mathrm{tCO}_{2} \mathrm{eha}^{-1} \mathrm{y}^{-1}\right)\end{array}$ & $\begin{array}{l}\mathrm{CH}_{4}-\mathrm{CO}_{2} \mathrm{e} \\
\left(\mathrm{tCO}_{2} \mathrm{eha}^{-1} \mathbf{y}^{-1}\right)\end{array}$ & $\begin{array}{l}\mathrm{N}_{2} \mathrm{O}-\mathrm{CO}_{2} \mathrm{e} \\
\left(\mathrm{t} \mathrm{CO} \mathrm{CO}_{2} \mathrm{ha}^{-1} \mathrm{y}^{-1}\right)\end{array}$ & $\begin{array}{l}\text { Net GWP } \\
\left(\operatorname{tCO}_{2} \mathrm{eha}^{-1} \mathbf{y}^{-1}\right)\end{array}$ & $\begin{array}{l}\text { GHGI } \\
\left(\mathrm{tCO}_{2} \mathrm{e} \mathrm{t}^{-1}\right. \\
\text { grain) }\end{array}$ \\
\hline CT & $11.14 \pm 0.58^{\mathrm{a}}$ & $-0.21 \pm 0.017^{b}$ & $0.035 \pm 0.004^{\mathrm{b}}$ & $10.96 \pm 0.56^{\mathrm{a}}$ & $17.21 \pm 1.18^{\mathrm{a}}$ \\
\hline CTS & $10.65 \pm 0.18^{\mathrm{a}}$ & $-0.23 \pm 0.005^{\mathrm{ab}}$ & $0.22 \pm 0.016^{\mathrm{a}}$ & $10.65 \pm 0.19^{\mathrm{a}}$ & $12.56 \pm 0.9^{\mathrm{ab}}$ \\
\hline NT & $7.37 \pm 0.89^{\mathrm{b}}$ & $-0.25 \pm 0.011^{\mathrm{ab}}$ & $0.18 \pm 0.075^{\mathrm{a}}$ & $7.30 \pm 0.97^{\mathrm{b}}$ & $10.37 \pm 2.34^{b}$ \\
\hline NTS & $6.65 \pm 0.73^{b}$ & $-0.27 \pm 0.024^{\mathrm{a}}$ & $0.17 \pm 0.016^{\mathrm{a}}$ & $6.55 \pm 0.70^{b}$ & $7.18 \pm 1.77^{b}$ \\
\hline
\end{tabular}

3 Note: The sign convention adopted is positive (+) means emission whilst negative (-) means 4 absorption.

5 


\section{Table 4(on next page)}

Correlation between Grain Yield and soil chemical properties

**Correlation is significant at the $\mathbf{0 . 0 1}$ level (2-tailed). *Correlation is significant at the 0.05 level (2-tailed). 
1 Table 4 Correlation between Grain Yield and soil chemical properties

Soil chemical property

Soil Organic Carbon (SOC)

Soil organic carbon at $10 \mathrm{~cm}$

Soil organic carbon at $20 \mathrm{~cm}$

Soil organic carbon at $40 \mathrm{~cm}$

Total Nitrogen (TN)

Total nitrogen at $10 \mathrm{~cm}$

Total nitrogen at $20 \mathrm{~cm}$

Total nitrogen at $40 \mathrm{~cm}$

**Correlation is significant at the 0.01 level (2-tailed).

3 *Correlation is significant at the 0.05 level (2-tailed).
$0.642 *$

$0.672 *$

$0.609 *$

Grain Yield

$0.614^{*}$

0.487

0.260

4

5 


\section{Table 5 (on next page)}

Correlation between greenhouse gases, soil temperature and soil water content 
1 Table 5. Correlation between greenhouse gases, soil temperature and soil water content

\begin{tabular}{|c|c|c|c|c|c|c|}
\hline \multirow[t]{3}{*}{ Treatment } & \multicolumn{3}{|c|}{ Soil temperature } & \multicolumn{3}{|c|}{ Soil water content } \\
\hline & \multirow[b]{2}{*}{ Equation } & \multirow[b]{2}{*}{$\mathrm{R}^{2}$} & \multicolumn{2}{|c|}{ Ecosystem respiration } & \multirow[b]{2}{*}{$\mathrm{R}^{2}$} & \multirow[b]{2}{*}{$p$-value } \\
\hline & & & $p$-value & Equation & & \\
\hline $\mathrm{CT}$ & $y=33.04 e^{0.07 x}$ & 0.68 & $<0.001$ & $y=363.57 x^{0.48}$ & 0.056 & $<0.01$ \\
\hline CTS & $y=32.55 e^{0.075}$ & 0.63 & $<0.001$ & $y=474.18 x^{0.67}$ & 0.095 & $<0.001$ \\
\hline NT & $y=21.58 e^{0.08 x}$ & 0.80 & $<0.001$ & $y=483.20 x^{0.88}$ & 0.138 & $<0.001$ \\
\hline \multirow[t]{2}{*}{ NTS } & $y=27.79 e^{0.077 x}$ & 0.80 & $<0.001$ & $y=317.12 x^{0.67}$ & 0.07 & $<0.001$ \\
\hline & & & \multicolumn{2}{|c|}{$\mathrm{CH}_{4}$ flux } & & \\
\hline $\mathrm{CT}$ & $y=-0.063 e^{0.012 x}$ & 0.019 & $=0.001$ & $y=-0.07-0.05 x$ & 0.03 & $=0.79$ \\
\hline CTS & $y=-0.052 e^{0.026 x}$ & 0.135 & $<0.001$ & $y=-0.08-0.02 x$ & 0.04 & $=0.87$ \\
\hline NT & $y=-0.062 e^{0.022 x}$ & 0.085 & $<0.001$ & $y=0.12-0.35 x$ & 0.1 & $=0.05$ \\
\hline \multirow[t]{2}{*}{ NTS } & $y=-0.068 e^{0.028 x}$ & 0.174 & $<0.001$ & $y=-0.04-0.31 x$ & 0.04 & $=0.137$ \\
\hline & & & \multicolumn{2}{|c|}{$\mathbf{N}_{2} \mathrm{O}$ flux } & & \\
\hline CT & $y=-0.84+0.12 x$ & 0.016 & $=0.456$ & $y=-2.45+26.62 x$ & 0.01 & $=0.269$ \\
\hline CTS & $y=-1.77+0.66 x$ & 0.209 & $<0.01$ & $y=-3.87+71.36 x$ & 0.08 & $=0.075$ \\
\hline NT & $y=4.64+0.12 x$ & 0.003 & $=0.65$ & $y=-0.68+43.45 x$ & 0.09 & $=0.055$ \\
\hline NTS & $y=2.05+0.28 x$ & 0.08 & $=0.07$ & $y=-3.6+48.92 x$ & 0.08 & $=0.067$ \\
\hline
\end{tabular}

2

3 